\title{
COVID-19 AND THE U.S.-CHINA COMPETITION: THE CASE OF ITALY
}

\author{
Dario Cristiani ${ }^{*}$ \\ Istituto Affari Internazionali, Rome \\ (C) D.Cristiani, 2020
}

DOI: 10.20542/2307-1494-2020-2-81-95

\begin{abstract}
After originating in China, the COVID-19 pandemic spread across the world. Italy was the next country severely hit by the outbreak of the Covid-19 pandemic, before the rest of Europe and the world. As Italy struggled to cope with this mounting crisis, China seized the momentum through an aggressive mix of public diplomacy, aid support and disinformation activities. By helping Italy, China pursued three goals: transforming its weaknesses in strengths by shifting the narrative over its handling of the COVID-19 crisis; promoting its management of the situation as the proof of the strength of its governance model; showing to the Italians, the Europeans and the world how Italy was benefitting from being a member of the Belt and Road Initiative. China's activism in Italy prompted reaction from the United States, and the COVID-19 strained relations between the two superpowers even further. While the idea that a new Cold War is brewing might be far-fetched, the relations between the two are now less and less cooperative. This increasing competition will also impact Italy's diplomatic freedom of action vis-à-vis China - a trend that is not set to change as the new J.Biden administration takes over in the United States, as his approach to China is likely to be less erratic and more consistent, but hardly softer than Trump's China policy.
\end{abstract}

Keywords Italy, China, United States, Covid-19, Belt and Road Initiative, multipolarity, great power politics

Название
статьи

Аннотация Возникнув в Китае, пандемия COVID-19 распространилась по всему миру. Италия оказалась следующей после Китая наиболее затронутой вспышкой пандемии COVID-19 страной по сравнению с остальными странами Европы и мира. В условиях, когда Италия с трудом справлялась с растущей угрозой, Китай воспользовался моментом, применив гремучую смесь из публичной дипломатии, помощи и дезинформации. Оказывая помощь Италии, Китай преследовал три цели: превратить свои слабые стороны в сильные, изменив дискурс о своих методах решения коронавирусного кризиса; представить китайскую модель борьбы с эпидемией как доказательство эффективности своей системы государственного управления; продемонстрировать итальянцам, другим европейцам, и всему миру все преимущества итальянского участия в «Инициативе Пояса и Пути». Активность Китая в Италии спровоцировала ответную реакцию со стороны США, и пандемия COVID-19 еще сильнее обострила и без того непростые отношения между

\footnotetext{
* Dario Cristiani (Italy) is a Senior Fellow at Instituto Affari Internazionali, Rome, and at German Marshall Fund, Washington D.C.

Дарио Кристиани (Италия) - старший научный сотрудник Института международных отношений (Рим) и Фонда Дж.Маршалла (Вашингтон).
} 
двумя сверхдержавами. Хотя предположения о некоей новой «холодной войне», возможно, преждевременны, взаимоотношения КНР и США становятся все менее конструктивными. Обострение американо-китайского соперничества также ограничит дипломатическую свободу маневра для Италии в отношении Китая. Эта тенденция вряд ли изменится с приходом к власти в США новой администрации Дж.Байдена: хотя его политика по отношению к Китаю будет менее хаотичной и более последовательной, она вряд ли окажется более мягкой, чем при Д.Трампе.

Ключевые Италия, Китай, CША, COVID-19, «Инициатива Пояса и Пути», многополярслова ность, политика великих держав

\section{Introduction}

In January 2020, news concerning a mysterious viral outbreak spreading across central China ${ }^{1}$ started hitting the headlines globally. Soon, China began to introduce a number of draconian measures to limit the epidemic. Initially, Beijing was somehow reluctantly admitting the actual nature and scale of the disease outbreak. It remained unclear to what extent this was due to China's unawareness of what was actually going on or to its intent to hide something.

However, as reports from China about the actual scale of this emerging threat were becoming more detailed and the pandemic started spreading worldwide, it became obvious that the world was about to face an actual global phenomenon, with a significant potential for disruption. Indeed, the pandemic has caused one of the worst economic crises in contemporary history and may catalyse a number of geopolitical shifts.

Many observers referred to this epidemic-turned-pandemic outbreak as a "black swan" - "an unpredictable or unforeseen event, typically one with extreme consequences", a concept popularised by Nassim Nicholas Taleb in his famous book "The Black Swan: The Impact of the Highly Improbable.".

Precisely like a black swan, a type of animal that exists in nature but is somewhat unique or, rather, is extremely rare, these types of event occur, once in a while, refuting any statistical logic and probabilities. However, while it is indisputable that the COVID-19 pandemic is an event with extreme consequences, whether it was an entirely "unpredictable or unforeseen" calamity remains open to debate.

Taleb himself criticised this view, insisting that such an event was "wholly predictable... a white swan if ever there was one". ${ }^{3}$ At the early stages of the pandemic outbreak, he also urged governments to "to kill it in the egg". 4

Indeed, the World Health Organisation (WHO) and other international institutions have warned for years about the risks of a pandemic outbreak. For instance, in September 2019, the Global Preparedness Monitoring Board (GPMB) openly admonished about the odds of a global pandemic, stressing that the world was "dangerously" underprepared to cope with such an emergency and that these risks were growing sharply. ${ }^{5}$

The hyperconnected nature of the current global system favoured the global spread of this disease before anyone could realise what was happening, and this dynamic made the pandemic a truly globalised emergency.

Following China, a number of other countries started to be hit by the virus. Rumours started to emerge that Iran was heavily hit by the pandemic as well. China's neighbours immediately started to feel the heat, given their connections with the giant neighbour state. In America, the first case of Coronavirus was recorded on 20 January: a 
man in the state of Washington, returning from Wuhan, was infected with coronaviruses. The infected man, 30 years old, a resident of Snohomish County, developed symptoms after returning on 15 January from a trip to the region where the outbreak began. ${ }^{6}$

On January 17, 2020, the international airports of New York, Los Angeles, and San Francisco started screening passengers arriving from China. A few days later, Atlanta and Chicago also began to carry out more thorough checks on travellers. In those weeks, the U.S. National Security Council's office on pandemics monitoring and prevention started to receive detailed intelligence reports outlining how the virus could have spread through the United States, with indications about possible lockdowns and city closures. ${ }^{7}$ Yet, the United States did not take early action. By late March, the pandemic hit the country heavily, making it the hardest hit in the world. However, among Western countries, Italy was the first to be dramatically hit by the virus, a few weeks earlier than the United States and other European countries.

\section{Italy, China and the pandemic}

Next to China, Italy soon became the hardest-hit country in the world, just before the pandemic turned genuinely global. By early March when cases started to increase exponentially, it became apparent that Italy was going to face once of the most significant challenges of its national history. The President of the Republic, Sergio Mattarella, openly compared the post-COVID-19 period to the period faced by Italians after WWII: ${ }^{8}$ a clear indication of how significant this challenge was as perceived by the Italians.

The crisis quickly acquired a multifaceted nature: it was not a mere sanitary emergency anymore, but became a political, institutional, economic, security, and even psychological emergency, with the entire Italian national territory in lockdown for weeks. As the first liberal democracy being hit by the pandemic, Italy had to strike a balance between public health concerns, economic problems, security and freedoms, showing how difficult it can be to impose restrictive public health measures in liberal-democratic contexts. ${ }^{9}$

Against this backdrop, China immediately assumed high relevance, on the one hand, as the country where this global emergency started and, on the other hand, as one of the most active and vocal countries in coming to Italy's rescue. As the crisis was unfolding globally, China launched a massive information campaign to shift the narrative, with a two-fold aim: magnifying the virtues of its management of the situation and spreading doubts on the actual origin of the pandemic. ${ }^{10}$ This came after Chinese President Xi Jinping called for a "people's war" against the virus to help to manage the threat domestically. ${ }^{11}$ Internationally, China felt it was under the West propaganda attack both on this and on a number of other issues. ${ }^{12}$

As the containment measures to deal with new cases of COVID-19 on its territory started having some effects, China embarked in a sort of global information war, trying to turn what was its weakness into a potential strength and using the know-how that Beijing built to cope with this pandemic and used as a sharp tool of sanitary diplomacy and soft power. In those days, all European countries rejected Italy's call for help, to the extent that the Italian ambassador to the EU officially admitted that Italy was left alone in a lack of solidarity among European countries. ${ }^{13}$ The images of the United States getting much-needed COVID-19 test kits transported into the U.S. by military plane added to the frustration of the Italian people. ${ }^{14}$

Against this backdrop, China wanted to highlight how it stepped in to help. Beijing tried to push the narrative that, while historical allies were turning their backs toward 
Rome, Beijing was instead ready to act. In a Facebook post "Beijing asks Chinese companies to send respirators and masks immediately to Italy", published in the account of the Chinese Embassy in Rome on March 10, 2020, the Chinese government announced its readiness to do "its part as a sign of deep thanks to Italy for helping the country in times of need". Following a telephone conversation between Chinese Foreign Minister Wang Yi and his Italian counterpart Luigi Di Maio, China supplied Italy with lung ventilators, masks, including high-tech ones, protective suits and swabs for coronavirus tests. $^{15}$

The message was that China decided to "donate" these materials to Italy. However, the reality was slightly different: only a small part was donated, while Italy purchased the rest. ${ }^{16}$ In parallel, the Italian Red Cross was also in touch with the Chinese Red Cross, and, on March 12, the Chinese Red Cross medics arrived. Interestingly enough, while in Italy, they made no mystery of their opinions regarding how Italy was dealing with the pandemic in the wrong way, saying that measures were not "severe enough". ${ }^{17}$

China grabbed the occasion to turn this non-governmental dynamic into a public relations stunt by arranging a charter of "China Eastern Airlines" that was allowed to pass as a "humanitarian flight", despite the ban for over flights from China. The arrival of this delegation, attended by the Chinese Ambassador, Li Junhua, was followed by the live streaming from Rome's Fiumicino airport. ${ }^{18}$

The picture of Chinese doctors coming to the rescue was compelling. These images, as well as the Facebook posts described above and many other public diplomacy activities, were widely shared on Italian social media sphere. These images came immediately after the news of Germany, France, and other European countries having acted selfishly. The comments of many ordinary Italians were highly critical of Italy's historical allies. It is hardly surprising that in those weeks there were mounting anti-European feelings in Italy and the hashtag \#ltalexit featured regularly featuring on Italian social media. ${ }^{19}$

For many Italians, the fact that European countries did eventually come to help, in the following weeks, was not very significant and did not change much. Many users were celebrating the Chinese efforts instead. Meanwhile, Chinese actions were more and more assuming the form of proper disinformation war waged through a host of social media accounts officially linked to China. ${ }^{20}$ China even tried to support a narrative that questioned the actual origin of the virus by suggesting, for instance, that is was a result of an American experiment, disseminating articles of conspiracy websites, ${ }^{21}$ or promoting the idea that there were suspicious cases of pneumonia in Italy related to COVID-19 already in November 2019. ${ }^{22}$

In the following days, this public diplomacy offensive continued, with the use of not only social media but also more traditional channels, and fake news openly spread. Chinese Foreign Ministry Spokesperson, Hua Chunying, posted a video on Twitter saying that Italians were chanting "Grazie, Cina!" ("Thank you, China") as the Chinese anthem was being played out in Rome. ${ }^{23}$

The Chinese approach towards Italy in the wake of the pandemic was actually driven by three major motivations. First, China saw an opportunity to take advantage of the emerging rift between Italy and its historical European and transatlantic allies and the mounting rage of the population for what the Italians perceived as a lack of European solidarity. By taking advantage of these dynamics Beijing wanted to increase its level of public and political engagement with Italy.

As for the European Union, China has neither an immediate interest nor a strategic interest in weakening the EU as an entity and a union, at least in the same way as other countries do. A united Europe is not perceived as a direct and urgent security threat to 
China. Still, the problems and disagreements between Italy and its European allies on how to handle the pandemic provided China with an excellent opportunity to shift the narrative: China, thus, transformed from the being the country where the pandemic started, partly due to the initial inaction, to the country that came to the rescue of developed countries suffering from the same problems and offered solutions, much needed biomedical support and especially know-how.

Second, China tried to promote solutions abroad based on what it did to manage the problem at home. By doing so, China was promoting and popularizing its model of governance. Some in Italy stressed how much the Chinese model was successful and efficient, suggesting that Italy should follow the same steps to cope with the pandemic. ${ }^{24}$

For China, whether a country - in this case, Italy - would actually follow these steps is not of principal importance per se. For Beijing, in order to build, little by little, step by step, its potential for global governance, it is essential that its model is taken into consideration and that there is a narrative suggesting that China's model can be successful. This is even more relevant as the U.S. leadership showed how unprepared it was to deal with this pandemic. Against this backdrop, China, through its medical help and the demonstrated effectiveness of its governance during the pandemic, has been working to build up the momentum and promote itself as a distinct pole of reference for the emergence of a new governance model.

Third, for China, this approach also served the purpose of strengthening its "Belt and Road Initiative" (BRI) - its global geoeconomic plan launched in 2013. Indeed, even before the pandemic, Italian-Chinese relations were already at the international spotlight as Italy became the first G7 country and EU founding member to formally join the Chinese BRI, as Rome signed the BRI Memorandum of Understanding (MoU) in March $2019 .{ }^{25}$ As the pandemic unfolded, Beijing wanted to advance the narrative of how Italy was benefiting from its deepening relations with Beijing, thanks to the adhesion to the $\mathrm{BRI}$, above all, by highlighting how Italy gained access to the so-called Health Silk Road. ${ }^{26}$

\section{The U.S.-China rivalry, Covid-19 and Italy's geostrategic orientation}

As shown above, China became extremely active vis-à-vis Italy during the COVID-19 pandemic, as it perceived this as an opportunity to turn the tide and regain the political initiative, globally, on confronting the pandemic. However, upon careful analysis of the results of these actions, Beijing's charm offensive toward Italy may actually be characterised as the one with mixed outcomes. These actions indeed strengthened China's image among the average Italians, but - paradoxically - undermined China's diplomatic and political strength having provoked a negative reaction from part of the Italian political world, particularly among the firmly Euro-Atlantic elites. ${ }^{27}$

On the one hand, a public opinion survey carried out by Italian Istituto Affari Internazionali (IAI) and the University of Siena clearly showed that Italians now consider China Italy's most important foreign friend. ${ }^{28}$

On the other hand, China's aggressive public diplomacy on the COVID-19 issues had unintended consequences for Beijing in Italy, as several political actors that historically were more nuanced and cautious toward China started becoming more vocally critical. For example, Democratic Party (PD - Partito Democratico) Defence Minister Lorenzo Guerini stressed that while Italy was "grateful to everyone for the aid", this did not signal any strategic shift as "the pillars of our Euro-Atlantic position... do not change". 29 
Italian Minister for the EU affairs from the same party, Enzo Amendola, stressed the need for a thorough inquiry into the responsibilities of China and the World Health Organization for the coronavirus pandemic, ${ }^{30}$ adding that the current government would not have signed on to the BRI as its predecessor did. He even envisaged a potential, more substantial relationship between Italy, the EU and India. ${ }^{31}$ The latter remains one of China's crucial competitor and a strategic rival, despite closer economic ties, ${ }^{32}$ as shown by the clashes in the western sector of the disputed border in the Himalayas, between Indian-controlled Ladakh and Chinese-controlled Aksai Chin. ${ }^{33}$

Among the parties forming the current Italian governmental coalition, the PD is and has for several years been - the most critical one towards China. However, as the pandemic crisis deteriorated, even the (previously) largely pro-China actors in the Italian political landscape started to shift their approach. This was the case of the Movimento 5 Stelle (M5S, or Five Star Movement).

On the Italian political landscape, the 5SM probably remains the most pro-China political actor, yet something has been changing. The movement has been a key proponent of Italy's closer ties to China since it entered the Italian parliament in $2013 .{ }^{34}$ Yet, this pro-China stance is now becoming less monolithic than previously thought. Speaking to "South China Morning Post" at the beginning of the COVID-19 crisis, Manlio Di Stefano, M5S undersecretary for foreign affairs, reiterated that "We want to be as close as possible [with China], but we know very well where we are: we are in Europe," also adding a more polemic note that "other Western countries were saying we cannot believe in [the] level playing field that China was granting to us, and we say we want to pay this political price, but we want to see the result at the end". ${ }^{35}$

Di Stefano words, at the time, were in line with those of Luigi di Maio, Italian M5S Foreign Minister. He said in a TV interview that "those who mocked us because we participated in the Belt and Road Initiative now have to admit that investing in that friendship allowed us to save lives in Italy". ${ }^{36}$ However, particularly in the case of Di Maio, this rhetoric gradually shifted. Weeks after he magnified the role that Italy's adhesion to the BRI had in helping Italy through the Covid-19 crisis, he noted that China is only "one of the partners with whom we hold dialogue frankly" and that Italy remains "committed to its Euro-Atlantic orientation". 37

Di Maio also changed his positions on vis-à-vis other crucial issues regarding China. For instance, on Hong Kong, in November 2019, he announced Italy's intention to support a "non-interference" approach, ${ }^{38}$ whereas in May 2020 he openly stressed that Italy wants to preserve "Hong Kong's stability, prosperity, autonomy and its system of freedom and fundamental rights". 39

Over the past two years, since China and Italy signed the Memorandum of Understanding on BRI, the issue of Italian-Chinese relations has come more and more to the spotlight. At the time of the MoU, the Italian Western allies had already started questioning Rome's intentions. ${ }^{40}$

The document, although not legally binding, was nevertheless so broad, generic, and comprehensive that it left room for it to be interpreted in several ways. As noted by one of the principal Italian China watchers, Alessia Amighini, the document showed a significant degree of confusion regarding the approach of the Italian government and, while the political costs attached to it were evident, the benefits were not as obvious. ${ }^{41}$

Indeed, from the Italian perspective, the BRI memorandum was not particularly significant and was not seen as a strategic shift. As such, it neither signalled any traumatic rupture with its historical allies, nor was it an attempt to shift eastward. Yet, many capitals reacted negatively to this development. 
The Italian Prime Minister, Giuseppe Conte, at that time had to deny that Italy would become China's "Troy Horse" in Europe. ${ }^{42} \mathrm{He}$ made clear that the MoU was coherent with EU rules and policies and in full agreement with the 2030 Agenda, the 2020 EU-China cooperation Agenda, and the EU Strategy for Eurasian connectivity.

This criticism resonated in the United States as well. American observers commented on Italy's new rapprochement with China with a mix of scepticism, hysteria and alarm. The New York Times, highlighting how Italy gave the Chinese President a "royal welcome", ${ }^{43}$ also added that the MoU on BRI proved that Italy was about to "structurally shift away from the West". ${ }^{44}$ The Washington Post said that Italy was "defiant", ${ }^{45}$ while Bloomberg described the Italian decision as a "snub to Washington". ${ }^{46}$

The U.S. approach well summarised what the dominant perception in Washington D.C. was at the time of the signing of the Chinese-Italian agreement. During the following months, the Italian diplomacy worked hard to accommodate the American concerns regarding the project. The outbreak of the Covid-19 pandemic added an additional element of complexity.

First, the pandemic resulted in a significant straining of relations between Washington and Beijing. The U.S. pressure on China regarding the origin of the virus and the handling of the crisis mounted. The abrupt shift in the rhetoric of President Donald Trump, who had initially praised the Chinese leadership and later started to refer to coronaviruses as either the "Wuhan virus", or the "Chinese virus", 47 signalled the beginning of a more intense phase of rivalry.

In the context of this re-emerging rivalry, Italy soon became one of its most important hotspots, as Washington became more and more concerned about Chinese activities in Italy. ${ }^{48}$ Indeed, the Presidential memorandum in which the Trump administration agreed to provide COVID-19 assistance to Italy was also issued to respond to the emerging Chinese activism.

In the context of soaring relations and the escalating confrontation, after years when the U.S.-China relations seemed to be able to move along a more cooperative path, ${ }^{49}$ some observers envisaged the emergence of a possible coexistence characterised by a significant degree of competition, ${ }^{50}$ while other talked about a new type of Cold War. ${ }^{51}$ Robert O'Brien, Trump's National Security Adviser, described China as a threat to the American democracy, ${ }^{52}$ suggesting a sort of ontological enmity between the two countries, similar to what the United States experienced with the Soviet Union.

China's rise is indisputable. Yet, whether the world is on the verge of experiencing a new holistic conflict between two unchallenged superpowers is not so obvious. China has yet to catch up with the United States on several, crucial issues, for instance, on technological and military capacities. ${ }^{53}$

As the BRI project moves ahead, Beijing also realises how its still limited capacities of projecting power abroad can undermine these efforts, particularly when it comes to protecting Chinese investments abroad. ${ }^{54}$ At the moment, China does not have the capability of competing with the United States in this domain.

Last but not least, China's many unresolved domestic problems - from ethnic troubles to geoeconomic cleavages, from pollution to demographic growth - can curb its rise at any time. ${ }^{55}$ The global system is indeed changing, but it is likely to be heading toward a multipolar, and not a bipolar, order.

The reality of the American-Chinese enmity and competition is not set to change as Joe Biden becomes the new U.S. President in January $2021,{ }^{56}$ as the concern about China's rise and actions has increasingly become a bipartisan issue in Washington. ${ }^{57}$ This has implications for Italy as well: the American pressure on Italy regarding its 
relations with China that were upgraded by the $\mathrm{BRI}$ MoU and in the wake of the COVID-19 crisis, will remain significant, reducing Italy's freedom of action in dealing with Beijing.

\section{Conclusions}

The impact of the ongoing coronavirus crisis is so significant that it has the potential to become a foundational moment in contemporary Italian history. This is a moment of profound distress when not only some of the social, political, and economic pillars face potential structural change, but Italy's international stance may also be affected. For instance, as the crisis unfolded, it became apparent that China tried to seize the momentum in Italy, driven by a three-fold goal: transforming its weaknesses in strengths by shifting the narrative over the Chinese handling of the COVID-19 crisis; promoting its management of the situation as the proof of the strengths of its governance model; and, last but not least, demonstrating to the Italians, the Europeans and the world how Italy was benefitting from being a member of the BRI.

In Italy as the country that was hit the hardest after China Beijing found a fertile soil to launch its initiative, an effort which was also favoured by several other circumstances. China's activities indeed gained particular attention in light of "the slow reaction by actors on which Italy has traditionally relied" and in the "lack of an efficient and pervasive communication strategy" which represented "another shortcoming in Europe's response". ${ }^{58}$ The same logic can be applied to the United States and its slow approach, both in dealing with the pandemic and in coming to rescue of its allies and partners. However, when it became clear that China was trying to make inroads into Italy, Washington became more active in trying to counter growing Chinese influence there.

However, China's aggressive public diplomacy in Italy regarding the COVID-19 crisis also had a number of unintended consequences. While Italian general public seemed to much appreciate the help and the efforts, the Italian political/institutional world started to become more wary about Chinese actions: not only political actors such as the PD, with some of its key leaders long cautious about engaging with China, but also the Italian Minister of Foreign Affairs Luigi Di Maio (previously considered to be one of the most pro-China actors in the Italian politics and the crucial actor behind Italy's decision to sign the BRI MoU with China) has toughened their rhetoric over China since the crisis broke out.

The current U.S.-China confrontation is not necessarily similar to the Cold War and the 20th century bipolar conflict. Beijing is still far from being a global military actor capable of confronting the United States. However, the COVID-19 crisis deepened the rift between two global powers that were trying to work together for some years. Trump's shifting rhetoric over the Chinese handling of the pandemic certainly played a role in straining relations. Still, China is seen as a systemic rival by the U.S. Democrats as well, and Biden's approach might be less erratic than Trump's, but not necessarily a softer one.

The U.S. attitude to Italy's moves concerning China will remain particularly significant even under the new administration. For Italy, developing its relationship with China does not necessarily mean that Rome is ready to abandon its Western allies and alliances to strengthen its relations with Beijing. Yet, the growing competition between the United States and China will inevitably reduce Rome's freedom of action in dealing with Beijing. Italian political players across the entire political spectrum are more and more aware of these emerging limitations. 
However, the magnitude of the current crisis, which is not over yet, has created some cracks. Economic and social problems will become more acute in Italy over the coming years. China will likely try to exploit these weaknesses again. If the new U.S. administration is not ready to reassure allies with swift and concrete actions, the Chinese diplomatic activism might find new domestic actors in Italy (and in broader Europe) willing to work more closely with Beijing, particularly if the shift in Italian public opinion sentiment toward China proves to be structural and not circumstantial.

\section{ENDNOTES}

${ }^{1}$ Dotson J. The state response to a mystery viral outbreak in Central China // China Brief: A Journal of Analysis and Information [Online journal]. V. 20. № 1. 2020. P. 1-5. URL: https://jamestown.org/wp-content/uploads/ 2020/01/Read-the-01-17-2020-CB-Issue_in_PDF.pdf.

2 Avishai B. The pandemic isn't a Black Swan but a portent of a more fragile global system // The New Yorker. 21 April 2020.

3 Ibid.

${ }^{4}$ Norman J., Bar-Yam Y., Taleb N.N. Systemic Risk of Pandemic via Novel Pathogens - Coronavirus: A Note. New England Complex Systems Institute [Cambridge, MA]. 26 January 2020; see also Avishai. Op. cit.

${ }^{5}$ Yeung J. The risk of a global pandemic is growing - and the world isn't ready, experts say // CNN. 18.09.2019. URL: https://www.cnn.com/2019/09/18/health/who-pandemic-report-intl-hnk-scli/ index.html.

${ }^{6}$ Rabin R.C. First patient with Wuhan coronavirus is identified in the U.S. // The New York Times. 21.01.2020.

${ }^{7}$ Lipton E., Sanger D., Haberman M., Shear M., Mazetti M., Barnes J. He could have seen what was coming: behind Trump's failure on the virus // The New York Times. 11.04.2020.

${ }^{8}$ Coronavirus, Mattarella: "Per rinascere ci è richiesta la stessa unità del dopoguerra" // La Repubblica. 24.03.2020.

${ }^{9}$ Cristiani D. Italy's Coronavirus Experience and the Challenge of Extreme Crises to Liberal Democracies: Transatlantic Take [Blog]. The German Marshall Fund of the United States. 20.03.2020.

URL: https://www.gmfus.org/blog/2020/03/20/italys-coronavirus-experience-and-challenge-extreme-crisesliberal-democracies.

10 Niquet V. China's coronavirus information warfare // The Diplomat. 24.03.2020.

URL: https://thediplomat.com/2020/03/chinas-coronavirus-information-warfare.

11 Xi focus: Xi vows to win People's War against novel coronavirus // Xinhua. 11.02.2020. URL:

http://www.xinhuanet.com/english/2020-02/11/c_138771934.htm.

${ }^{12}$ China needs to counter Western public opinion war // Global Times. 25.11.2019.

URL: http://www.globaltimes.cn/content/1171174.shtml.

${ }^{13}$ Massari M. Italian Ambassador to the EU: Italy needs Europe's help // Politico (Europe). 10.03.2020. URL: https://www.politico.eu/article/coronavirus-italy-needs-europe-help.

${ }^{14}$ Coronavirus, mezzo milione di tamponi da un'azienda di Brescia agli Stati Uniti // La Repubblica. 19.03.2020. 
15 Pechino Chiede Alle Aziende Cinesi di "Inviare Immediatamente in Italia Respiratori e Mascherine". Ambasciata della Repubblica Popolare Cinese in Italia. Facebook Account. 10.03.2020. URL: https://www.facebook.com/chineseembassyitaly/photos/a.712402095490257/2934165169980594/?type=3\&t heater.

${ }^{16}$ Pompili G. Ma quali aiuti della Cina contro il virus, è tutta roba che compriamo // II Foglio. 12.03.2020.

URL: https://www.ilfoglio.it/cronache/2020/03/12/news/ma-quali-aiuti-della-cina-contro-il-virus-e-tutta-robache-compriamo-306324.

17 Coronavirus, la Croce Rossa cinese: “Misure non abbastanza severe, va chiuso tutto. Non c'è seconda scelta di fronte alla vita" // II Fatto Quotidiano. 19.03.2020. URL: https://www.ilfattoquotidiano.it/2020/03/19/ coronavirus-la-croce-rossa-cinese-misure-non-abbastanza-severe-va-chiuso-tutto-non-ce-seconda-scelta-difronte-alla-vita/5742195.

18 Pompili G. Che cosa c'è dietro il mistero della donazione cinese all'Italia // II Foglio. 13.03.2020. URL: https://www.ilfoglio.it/politica/2020/03/13/news/che-cosa-c-e-dietro-il-mistero-della-donazione-cinese-allitalia-306507.

${ }^{19}$ Mercuri G. Da Draghi a Lagarde: la Bce e il rischio che I'Italia si senta abbandonata dall'Europa // Corriere della Sera. 17.03.2020.

20 Così la Cina fa propaganda in Italia, con i bot. Ecco I'analisi su Twitter di Alkemy per Formiche // Formiche.net. 30.03.2020. URL: https://formiche.net/2020/03/cina-propaganda-twitter-bot-alkemy.

${ }^{21}$ Zhao L. This Article is Very Much Important to Each and Every One of Us. Please Read and Retweet It. COVID19: Further Evidence That the Virus Originated in the US. Lijian Zhao 赵立坚 Twitter. 13.03.2020.

URL: https://twitter.com/zlj517/status/1238269193427906560.

22 \#Italy May Have Had an Unexplained Strain of Pneumonia as Early as November and December 2019 with Highly Suspected Symptoms of \#COVID19, Reports Said. @globaltimesnews. Global Times Twitter. 22.03.2020. URL: https://twitter.com/globaltimesnews/status/1241559268190343168.

${ }^{23}$ Chunying H. Amid the Chinese Anthem Playing out in Rome, Italians Chanted "Grazie, Cina!". In This Community with a Shared Future, We Share Weal and Woe Together. @spokespersonchn. Hua Chunying 华春 芗 Twitter. 15.03.2020. URL: https://twitter.com/spokespersonchn/status/1239041044580188162.

${ }^{24}$ Santevecchi G. Coronavirus, così il modello Cinese ha funzionato: soltanto 36 nuovi casi a Wuhan // Corriere Della Sera. 09.03.2020.

${ }^{25}$ Memorandum d'Intesa tra il Governo della Repubblica Italiana e il Governo della Repubblica Popolare Cinese Sulla Collaborazione Nell'Ambito della "Via della Seta Economica" e dell' "Iniziativa per Una Via della Seta Marittima del $21^{\circ}$ Secolo". Italian Government. March 2019. URL: http://www.governo.it/sites/governo.it/ files/Memorandum_Italia-Cina_IT.pdf.

${ }^{26}$ Lancaster K., Rubin M., Rapp-Hooper M. Mapping China's Health Silk Road. Asia Unbound: Council on Foreign Relations [Blog]. 10.04.2020. URL: https://www.cfr.org/blog/mapping-chinas-health-silk-road.

${ }^{27}$ Cristiani D. China's Charm Offensive Meets Italy's Euro-Atlantic Resilience. Transatlantic Take [Blog]. The German Marshall Fund of the United States. 9.06.2020. URL: https://www.gmfus.org/blog/2020/06/09/chinascharm-offensive-meets-italys-euro-atlantic-resilience.

${ }^{28}$ Emergenza Coronavirus e Politica Estera: L'Opinione degli Italiani sul Governo, l'Europa e la Cooperazione Internazionale. - Rome: Istituto Affari Internazionali; Laboratorio Analisi Politiche e Sociali, Dipartimento di Scienze Sociali, Politiche e Cognitive, Università di Siena, May 2020. 
${ }^{29}$ Lorenzo Guerini: "Ue e Nato i nostri pilastri, serve trasparenza sull'origine del virus" // La Repubblica. 04.05.2020.

30 "La Cina? L'Italia non si opporrà a un'indagine sull'origine del virus", parla il ministro Amendola // II Foglio. 07.05.2020. URL: https://www.ilfoglio.it/politica/2020/05/07/news/la-cina-litalia-non-si-opporra-a-unindaginesullorigine-del-virus-parla-il-ministro-amendola-316991.

31 Italy wants independent probe into origin of pandemic, backs India's call for reform of WHO: Italian minister // Hindustan Times. 30.05.2020. URL: https://www.hindustantimes.com/world-news/italy-wants-independentprobe-into-origin-of-pandemic-backs-india-s-call-for-reform-of-who-italian-minister/storyVdRZCzTS9DWhv8tuofQoJJ.html.

32 Ollapally D.M. China and India: economic ties and strategic rivalry // Orbis. V. 58. № 3. 2014. P. 342-357.

${ }^{33}$ Sun Y. China's strategic assessment of the Ladakh clash // War on the Rocks. 19.06.2020. URL: http://warontherocks.com/2020/06/chinas-strategic-assessment-of-the-ladakh-clash.

${ }^{34}$ De Maio G. Playing with Fire: Italy, China, and Europe. Brookings Institute - Robert Bosch Foundation Transatlantic Initiative. The New Geopolitics: Europe. - Washington D.C.: Brookings Institute, May 2020. P. 11. URL: https://www.brookings.edu/research/playing-with-fire.

35 Italy "still proud to be part of EU" amid stronger ties with China // South China Morning Post. 2.04.2020. URL: https://www.scmp.com/news/china/diplomacy/article/3077985/italy-still-proud-be-part-eu-amidstronger-ties-china.

${ }^{36}$ Luigi Di Maio Ospite a TG2 Post Rai 2. [Video]. 24.03.2020.

URL: https://www.youtube.com/watch?v= 0W7JRf6qaog.

37 Buzzi E. Parla Di Maio: "La Cina è un partner, ma i nostri valori sono quelli della Nato" // Corriere della Sera. 6.05.2020.

38 Di Maio: Non interferiamo su Hong Kong // Ansa. 5.11.2019. URL: https://www.ansa.it/sito/notizie/ topnews/2019/11/05/di-maio-non-interferiamo-su-hong-kong_4019d8ee-ebf1-4d3b-96dc-c19a16e7155f.html.

39 Hong Kong: "Seria preoccupazione" dell'Italia. Ue contraria a sanzioni // Agi. 29.05.2020.

URL: https://www.agi.it/estero/news/2020-05-29/hong-kong-seria-preoccupazione-italia-ue-contraria-sanzioni -8766220 .

40 Silk Road opens a rift in Italy's Government // Politico (Europe). 13.03.2019.

URL: https://www.politico.eu/article/italy-comes-to-silk-road-juncture-with-chinese-mou.

41 Amighini A. Italia-Cina: quel Memorandum è un pasticcio // Lavoce.info. 15.03.2019.

URL: https://www.lavoce.info/archives/58076/italia-cina-quel-memorandum-e-un-pasticcio.

${ }^{42}$ Fontana L., Franco M. Via dell Seta, intervista a Conte: "Italia-Cina, intesa limpida: il nostro obiettivo è quello di crescere" // Corriere della Sera. 13.03.2019.

43 Horowitz J., Erlanger S. Italy gives Xi, and China's vast infrastructure project, a royal welcome // The New York Times. 22.03.2019.

${ }^{44}$ Horowitz J. Italy's deal with China signals a shift as U.S. influence recedes // The New York Times. 1.04.2019.

${ }^{45}$ Harlan C. A defiant Italy becomes the first G-7 country to sign on to China's Belt and Road Initiative // The Washington Post. 22.03.2019. 
46 Italy's embrace of China's "Belt and Road" is a snub to Washington // Bloomberg. 19.03.2019. URL: https://www.bloomberg.com/news/articles/2019-03-19/italy-s-embrace-of-china-s-belt-and-road-is-a-snub-towashington.

47 Lindaman D., Viala-Gaudefroy G. Donald Trump's "Chinese virus": the politics of naming // The Conversation. 21.04.2020. URL: http://theconversation.com/donald-trumps-chinese-virus-the-politics-ofnaming-136796.

${ }^{48}$ Alcaro R. COVID-19 Exposes Italy's Vulnerability to US-China Antagonism. IAI Commentary. - Rome: Istituto Affari Internazionali, 8.05.2020. URL: https://www.iai.it/en/pubblicazioni/covid-19-exposes-italys-vulnerabilityus-china-antagonism.

49 Zakaria F. The new China scare // Foreign Affairs. January/February 2020.

URL: https://www.foreignaffairs. com/articles/china/2019-12-06/new-china-scare.

${ }^{50}$ Erickson A.S. Competitive coexistence: an American concept for managing U.S.-China relations // The National Interest. 30.01.2019. URL: https://nationalinterest.org/feature/competitive-coexistence-americanconcept-managing-us-china-relations-42852.

51 Politi J., Manson K., Kynge J. US and China: edging towards a new type of Cold War? // Financial Times. 8 May 2020.

52 O'Brien R.C. How China threatens American democracy // Foreign Affairs. 29 October 2020.

URL: https://www.foreignaffairs.com/articles/china/2020-10-21/how-china-threatens-american-democracy.

${ }^{53}$ Gilli A., Gilli M. Why China has not caught up yet: military-technological superiority and the limits of imitation, reverse engineering, and cyber espionage // International Security. V. 43. № 3. Winter 2018/2019. P. 141-189.

54 Legarda H., Nouwens M. Guardians of the Belt and Road: The Internationalization of China's Private Security Companies. Mercator Institute for China Studies (MERICS) [Berlin]. 16 August 2018.

URL: https://merics.org/en/report/guardians-belt-and-road.

55 Pei M. China's coming upheaval // Foreign Affairs. May/June 2020. P. 82-95.

URL: https://www.foreignaffairs.com/ articles/united-states/2020-04-03/chinas-coming-upheaval.

${ }^{56}$ Baer D. America under Biden won't go soft on China // Foreign Policy. 6.11.2020.

URL: https://foreignpolicy.com/2020/11/06/biden-china-trump-election.

57 Goldberg C., Schneider J. A divided Washington is (sort of) united on China // Foreign Policy. 9.11.2020. URL: https://foreignpolicy.com/2020/11/09/biden-china-republicans-democrats-congress.

58 Ghiretti F. China, Italy and COVID-19: Benevolent Support or Strategic Surge? IAI Commentary. 26 March 2020. URL: https://www.iai.it/en/pubblicazioni/china-italy-and-covid-19-benevolent-support-or-strategicsurge.

\section{BIBLIOGRAPHY}

1. Alcaro R. COVID-19 Exposes Italy's Vulnerability to US-China Antagonism. IAI Commentary. Rome: Istituto Affari Internazionali, 8.05.2020. URL: https://www.iai.it/en/pubblicazioni/covid-19exposes-italys-vulnerability-us-china-antagonism.

2. Amighini A. Italia-Cina: quel Memorandum è un pasticcio // Lavoce.info. 15.03.2019.

URL: https://www.lavoce.info/archives/58076/italia-cina-quel-memorandum-e-un-pasticcio.

3. Avishai B. The pandemic isn't a Black Swan but a portent of a more fragile global system // The New Yorker. 21 April 2020. 
4. Baer D. America under Biden won't go soft on China // Foreign Policy. 6 November 2020.

URL: https://foreignpolicy.com/2020/11/06/biden-china-trump-election.

5. Buzzi E. Parla Di Maio: "La Cina è un partner, ma i nostri valori sono quelli della Nato" // Corriere della Sera. 06.05.2020.

6. China needs to counter Western public opinion war // Global Times. 25.11.2019.

URL: http://www.globaltimes.cn/content/1171174.shtml.

7. Chunying H. Amid the Chinese Anthem Playing out in Rome, Italians Chanted "Grazie, Cina!". In This Community with a Shared Future, We Share Weal and Woe Together. @spokespersonchn.

Hua Chunying 华春莹 Twitter. 15.03.2020. URL: https://twitter.com/spokespersonchn/status/ 1239041044580188162.

8. Coronavirus, la Croce Rossa cinese: "Misure non abbastanza severe, va chiuso tutto. Non c'è seconda scelta di fronte alla vita" // II Fatto Quotidiano. 19.03.2020.

URL: https://www.ilfattoquotidiano.it/2020/03/19/ coronavirus-la-croce-rossa-cinese-misure-nonabbastanza-severe-va-chiuso-tutto-non-ce-seconda-scelta-di-fronte-alla-vita/5742195.

9. Coronavirus, Mattarella: "Per rinascere ci è richiesta la stessa unità del dopoguerra" // La Repubblica. 24.03.2020.

10. Coronavirus, mezzo milione di tamponi da un'azienda di Brescia agli Stati Uniti // La Repubblica. 19.03.2020.

11. Così la Cina fa propaganda in Italia, con i bot. Ecco l'analisi su Twitter di Alkemy per Formiche // Formiche.net. 30.03.2020. URL: https://formiche.net/2020/03/cina-propaganda-twitter-bot-alkemy.

12. Cristiani D. China's Charm Offensive Meets Italy's Euro-Atlantic Resilience. Transatlantic Take [Blog]. The German Marshall Fund of the United States. 09.06.2020. URL: https://www.gmfus. org/blog/2020/06/09/chinas-charm-offensive-meets-italys-euro-atlantic-resilience.

13. Cristiani D. Italy's Coronavirus Experience and the Challenge of Extreme Crises to Liberal Democracies: Transatlantic Take [Blog]. The German Marshall Fund of the United States. 20.03.2020. URL: https://www.gmfus.org/blog/2020/03/20/italys-coronavirus-experience-andchallenge-extreme-crises-liberal-democracies.

14. De Maio G. Playing with Fire: Italy, China, and Europe. Brookings Institute - Robert Bosch Foundation Transatlantic Initiative. The New Geopolitics: Europe. - Washington D.C.: Brookings Institute, May 2020. P. 11. URL: https://www.brookings.edu/research/playing-with-fire.

15. Di Maio: Non interferiamo su Hong Kong // Ansa. 05.11.2019. URL: https://www.ansa.it/ sito/notizie/ topnews/2019/11/05/di-maio-non-interferiamo-su-hong-kong_4019d8ee-ebf1-4d3b96dc-c19a16e7155f.html.

16. Dotson J. The state response to a mystery viral outbreak in Central China // China Brief: A Journal of Analysis and Information [Online journal]. V. 20. № 1. 2020. P. 1-5.

URL: https://jamestown.org/wp-content/uploads/2020/01/Read-the-01-17-2020-CB-Issue in PDF.pdf.

17. Emergenza Coronavirus e Politica Estera: L'Opinione degli Italiani sul Governo, I'Europa e la Cooperazione Internazionale. - Rome: Istituto Affari Internazionali; Laboratorio Analisi Politiche e Sociali, Dipartimento di Scienze Sociali, Politiche e Cognitive, Università di Siena, May 2020.

18. Erickson A.S. Competitive coexistence: an American concept for managing U.S.-China relations // The National Interest. 30 January 2019. URL: https://nationalinterest.org/feature/competitivecoexistence-american-concept-managing-us-china-relations-42852.

19. Fontana L., Franco M. Via dell Seta, intervista a Conte: "Italia-Cina, intesa limpida: il nostro obiettivo è quello di crescere" // Corriere della Sera. 13.03.2019.

20. Ghiretti F. China, Italy and COVID-19: Benevolent Support or Strategic Surge? Istituto Affari Internazionali (IAI) Commentary. 26 March 2020. URL: https://www.iai.it/en/pubblicazioni/ chinaitaly-and-covid-19-benevolent-support-or-strategic-surge.

21. Gilli A., Gilli M. Why China has not caught up yet: military-technological superiority and the limits of imitation, reverse engineering, and cyber espionage // International Security. V. 43. № 3. Winter 2018/2019. P. 141-189. DOI: 10.1162/isec_a_00337.

URL: https://www.mitpressjournals.org/doi/full/10.1162/isec_a_00337.

22. Goldberg C., Schneider J. A divided Washington is (sort of) united on China // Foreign Policy. 9 November 2020. URL: https://foreignpolicy.com/2020/11/09/biden-china-republicans-democratscongress.

23. Harlan C. A defiant Italy becomes the first G-7 country to sign on to China's Belt and Road Initiative // The Washington Post. 22 March 2019.

24. Hong Kong: "Seria preoccupazione" dell'Italia. Ue contraria a sanzioni // Agi. 29.05.2020. 
URL: https://www.agi.it/estero/news/2020-05-29/hong-kong-seria-preoccupazione-italia-uecontraria-sanzioni -8766220 .

25. Horowitz J. Italy's deal with China signals a shift as U.S. influence recedes // The New York Times. 1 April 2019.

26. Horowitz J., Erlanger S. Italy gives Xi, and China's vast infrastructure project, a royal welcome // The New York Times. 22 March 2019.

27. \#ltaly May Have Had an Unexplained Strain of Pneumonia as Early as November and December 2019 with Highly Suspected Symptoms of \#COVID19, Reports Said. @globaltimesnews. Global Times Twitter. 22.03.2020. URL: https://twitter.com/globaltimesnews/status/12415592681 90343168.

28. Italy "still proud to be part of EU" amid stronger ties with China // South China Morning Post. 02.04.2020. URL: https://www.scmp.com/news/china/diplomacy/article/3077985/italy-still-proudbe-part-eu-amid-stronger-ties-china.

29. Italy wants independent probe into origin of pandemic, backs India's call for reform of WHO: Italian minister // Hindustan Times. 30.05.2020. URL: https://www.hindustantimes.com/worldnews/italy-wants-independent-probe-into-origin-of-pandemic-backs-india-s-call-for-reform-of-whoitalian-minister/story-VdRZCzTS9DWhv8tuofQoJJ.html.

30. Italy's embrace of China's "Belt and Road" is a snub to Washington // Bloomberg. 19.03.2019. URL: https://www.bloomberg.com/news/articles/2019-03-19/italy-s-embrace-of-china-s-belt-androad-is-a-snub-to-washington.

31. "La Cina? L'Italia non si opporrà a un'indagine sull'origine del virus", parla il ministro Amendola // II Foglio. 07.05.2020. URL: https://www.ilfoglio.it/politica/2020/05/07/news/la-cina-litalia-non-siopporra-a-unindagine-sullorigine-del-virus-parla-il-ministro-amendola-316991.

32. Lancaster K., Rubin M., Rapp-Hooper M. Mapping China's Health Silk Road. Asia Unbound: Council on Foreign Relations [Blog]. 10.04.2020. URL: https://www.cfr.org/blog/mapping-chinashealth-silk-road.

33. Legarda H., Nouwens M. Guardians of the Belt and Road: The Internationalization of China's Private Security Companies. Mercator Institute for China Studies (MERICS) [Berlin]. 16 August 2018. URL: https://merics.org/en/report/guardians-belt-and-road.

34. Lindaman D., Viala-Gaudefroy G. Donald Trump's "Chinese virus": the politics of naming // The Conversation. 21.04.2020. URL: http://theconversation.com/donald-trumps-chinese-virusthe-politics-of-naming-136796.

35. Lipton E., Sanger D., Haberman M., Shear M., Mazetti M., Barnes J. He could have seen what was coming: behind Trump's failure on the virus // The New York Times. 11 April 2020.

36. Lorenzo Guerini: "Ue e Nato i nostri pilastri, serve trasparenza sull'origine del virus" // La Repubblica. 04.05.2020.

37. Luigi Di Maio Ospite a TG2 Post Rai 2. [Video]. 24.03.2020. URL: https://www.youtube.com/ watch?v= 0W7JRf6qaog.

38. Massari M. Italian Ambassador to the EU: Italy needs Europe's help // Politico (Europe). 10.03.2020. URL: https://www.politico.eu/article/coronavirus-italy-needs-europe-help.

39. Memorandum d'Intesa tra il Governo della Repubblica Italiana e il Governo della Repubblica Popolare Cinese Sulla Collaborazione Nell'Ambito della "Via della Seta Economica" e dell' "Iniziativa per Una Via della Seta Marittima del 21 Secolo". Italian Government. March 2019. URL: http://www.governo.it/sites/governo.it/ files/Memorandum_Italia-Cina_IT.pdf.

40. Mercuri G. Da Draghi a Lagarde: la Bce e il rischio che l'Italia si senta abbandonata dall'Europa // Corriere della Sera. 17.03.2020.

41. Niquet V. China's coronavirus information warfare // The Diplomat. 24.03.2020. URL: https://thediplomat.com/2020/03/chinas-coronavirus-information-warfare.

42. Norman J., Bar-Yam Y., Taleb N.N. Systemic Risk of Pandemic via Novel Pathogens Coronavirus: A Note. New England Complex Systems Institute [Cambridge, MA]. 26 January 2020.

43. O'Brien R.C. How China threatens American democracy // Foreign Affairs. 29 October 2020. URL: https://www.foreignaffairs.com/articles/china/2020-10-21/how-china-threatens-americandemocracy.

44. Ollapally D.M. China and India: economic ties and strategic rivalry // Orbis. V. 58. № 3. 2014. P. 342-357. DOI: 10.1016/j.orbis.2014.05.003.

45. Pechino Chiede Alle Aziende Cinesi di "Inviare Immediatamente in Italia Respiratori e Mascherine". Ambasciata della Repubblica Popolare Cinese in Italia. Facebook Account. 
10.03.2020. URL: https://www.facebook.com/chineseembassyitaly/photos/a.712402095490257/ 2934165169980594/?type=3\&theater.

46. Pei M. China's coming upheaval // Foreign Affairs. May/June 2020. P. 82-95.

URL: https://www.foreignaffairs.com/ articles/united-states/2020-04-03/chinas-coming-upheaval.

47. Politi J., Manson K., Kynge J. US and China: edging towards a new type of Cold War? // Financial Times. 8 May 2020.

48. Pompili G. Che cosa c'è dietro il mistero della donazione cinese all'Italia // II Foglio. 13.03.2020.

URL: https://www.ilfoglio.it/politica/2020/03/13/news/che-cosa-c-e-dietro-il-mistero-delladonazione-cinese-all-italia-306507.

49. Pompili G. Ma quali aiuti della Cina contro il virus, è tutta roba che compriamo // II Foglio. 12.03.2020. URL: https://www.ilfoglio.it/cronache/2020/03/12/news/ma-quali-aiuti-della-cinacontro-il-virus-e-tutta-roba-che-compriamo-306324.

50. Rabin R.C. First patient with Wuhan coronavirus is identified in the U.S. // The New York Times. 21 January 2020.

51. Santevecchi G. Coronavirus, così il modello Cinese ha funzionato: soltanto 36 nuovi casi a Wuhan // Corriere Della Sera. 09.03.2020.

52. Silk Road opens a rift in Italy's Government // Politico (Europe). 13.03.2019.

URL: https://www.politico.eu/article/italy-comes-to-silk-road-juncture-with-chinese-mou.

53. Sun Y. China's strategic assessment of the Ladakh clash // War on the Rocks. 19.06.2020.

URL: http://warontherocks.com/2020/06/chinas-strategic-assessment-of-the-ladakh-clash.

54. Taleb N.N. The Black Swan: The Impact of the Highly Improbable. - London: Random House, 2009.

55. Zhao L. This Article is Very Much Important to Each and Every One of Us. Please Read and Retweet It. COVID-19: Further Evidence That the Virus Originated in the US. Lijian Zhao 赵立坚 Twitter. 13.03.2020. URL: https://twitter.com/zlj517/status/1238269193427906560.

56. Xi focus: Xi vows to win People's War against novel coronavirus // Xinhua. 11.02.2020. URL: http://www.xinhuanet.com/english/2020-02/11/c_138771934.htm.

57. Yeung $\mathrm{J}$. The risk of a global pandemic is growing - and the world isn't ready, experts say // CNN. 18.09.2019. URL: https://www.cnn.com/2019/09/18/health/who-pandemic-report-intl-hnkscli/ index.html.

58. Zakaria F. The new China scare // Foreign Affairs. January/February 2020.

URL: https://www.foreignaffairs. com/articles/china/2019-12-06/new-china-scare. 